\title{
Inflammatory Cytokines Stimulate the Adhesion of Colon Carcinoma Cells to Mesothelial Monolayers
}

\author{
W. M. U. van Grevenstein • L. J. Hofland • \\ M. E. E. van Rossen • P. M. van Koetsveld • J. Jeekel • \\ C. H. J. van Eijck
}

Received: 5 October 2006 / Accepted: 18 January 2007 / Published online: 30 March 2007

(C) Springer Science+Business Media, LLC 2007

\begin{abstract}
Surgical handling of the peritoneum causes an inflammatory reaction, during which a potentially lethal cocktail of active mediators is produced, including cytokines and growth factors. The aim of this study was to investigate the effects of inflammatory cytokines on the interaction between tumor and mesothelial cells. Tumor cell adhesion to a mesothelial monolayer was assessed after preincubation of the mesothelium with interleukin (IL)- $1 \beta$, IL-6, and tumor necrosis factor (TNF) $-\alpha$.

Preincubation of the mesothelial monolayer with IL- $1 \beta$ or TNF- $\alpha$ resulted in enhanced tumor cell adhesion of Caco2 and HT29 colon carcinoma cells. The amount of stimulation for the Caco2 cells was between $20 \%$ and $40 \%$ and for HT29 cells between $30 \%$ and $70 \%$. Blocking experiments with anti-IL- $1 \beta$ and anti-TNF- $\alpha$ resulted in significant inhibition of the cytokine-stimulated tumor cell adhesion. The presented results prove that IL- $1 \beta$ and TNF- $\alpha$ are significant stimulating factors in tumor cell adhesion in vitro and may therefore account for tumor recurrence to the peritoneum in vivo.
\end{abstract}

Keywords Colon carcinoma cells · Mesothelium . Cytokines $\cdot$ Adhesion molecules $\cdot$ Recurrence

W. M. U. van Grevenstein · M. E. E. van Rossen · J. Jeekel ·

C. H. J. van Eijck

Laboratories for Experimental Surgery and Oncology,

Erasmus MC Rotterdam, The Netherlands

L. J. Hofland · P. M. van Koetsveld

Department of Internal Medicine,

Erasmus MC Rotterdam, The Netherlands

W. M. U. van Grevenstein $(\bowtie)$

Erasmus MC, Department of Surgery,

PO Box 2040, 3000 CA Rotterdam, The Netherlands

e-mail: vangrevenstein@hotmail.com
Colorectal cancer accounts for over half of the cases of gastrointestinal malignancy. Several new adjuvant treatment modalities improved the overall 5-year survival rate for colorectal carcinomas in the last decade. The most recent 5-year survival rates are, according to a study from France, 36.1\% for local recurrence and $24 \%$ for distant metastases [1]. In the United States, $80 \%$ of patients with colorectal cancer present with local or locally advanced disease and for this group curative surgery can be attempted. However, up to $40 \%$ of these patients develop recurrent disease [2]. Despite adjuvant chemotherapy, locoregional and distant recurrence remain a major problem with colorectal cancer. The most common site for colorectal adenocarcinoma to recur is the site of the primary tumor; the second is the peritoneal surface [3]. Therefore, elimination of locoregional recurrence in the peritoneal cavity may be benefit a significant proportion of patients in terms of survival or quality of life. A better understanding of the pathophysiology of tumor recurrence may lead to more specific tools to confront the initial process of implantation.

Despite preoperative precautions, tumor spill and subsequent implantation, colonization, and growth of these cells in the peritoneal cavity on either intact or traumatized mesothelium and extracellular matrix is an important mechanism accounting for tumor recurrence. Wound healing after surgical trauma induces an inflammatory response during which high amounts of cytokines and growth factors are produced [4-6]. These inflammatory mediators are known to upregulate adhesion molecules and therefore offer an exceptional environment for the tumor cells to adhere [7-9].

The aim of this study was to elucidate the role of cytokines with regard to influencing seeding and colonization of tumor cells to the surgically traumatized peritoneal surface. Therefore, we developed an in vitro model to investigate the role of several major inflammatory cytokines, namely, interleukin 
(IL)- $1 \beta$, IL-6, and tumor necrosis factor (TNF)- $\alpha$, on the interaction between human mesothelial cells (MC) and colon carcinoma cells. We studied the adhesion of Caco2 and HT29 cells on omental-derived MC. Furthermore, we studied the expression of adhesion molecules and counterparts on the cells used in this study by immunohistochemistry to determine the potential interaction sites between the cells.

\section{Materials and methods}

Culture and identification of omental mesothelial cells

MC were obtained from the omental tissue of patients undergoing elective abdominal surgery. All patients gave informed consent. The MC were isolated according to techniques modified from Nicholson et al [10] and Wu et al [11]. The omentum was transferred to fluid containing $0.05 \%$ trypsin0.02\% EDTA (Invitrogen, Karlsruhe, Germany). After 15 minutes, the detached $\mathrm{MC}$ were pelleted by centrifugation at $450 \mathrm{~g}$ for 10 minutes and were resuspended in RPMI 1640 supplemented with $10 \%$ fetal calf serum (FCS), L-glutamin (200 mmol/L), and penicillin (5000 U/mL; Invitrogen). MC were grown to confluence in a $37^{\circ} \mathrm{C}$, fully humidified, $5 \%$ $\mathrm{CO}_{2}$ cabinet in polystyrene culture flasks $\left(75 \mathrm{~cm}^{2}\right.$; Corning, Schiphol-Rijk, The Netherlands), precoated with collagen type I $\left(17.5 \mu \mathrm{g} / \mathrm{cm}^{2}\right)$. The identity of MC was demonstrated by the absence of von Willebrand factor staining [12] and the presence of intracellular cytokeratins [13] via immunohistologic staining with monoclonal antibodies (Dako, Amsterdam, The Netherlands).

\section{Tumor cell line}

The human colon adenocarcinoma Caco-2 and HT29 were kind gifts of Dr W. Dinjens and are both mucinous adenocarcinoma. Both cell lines were cultured in RPMI medium supplemented with $10 \%$ FCS, L-glutamin (200 mmol/L), and penicillin $(5000 \mathrm{U} / \mathrm{mL})$. All supplements were obtained from Invitrogen. Before use, cells were trypsinized ( $5 \mathrm{~min}-$ utes at $37^{\circ} \mathrm{C}$ ), centrifuged ( 5 minutes at $400 \mathrm{~g}$ ), resuspended in RPMI, and counted. Viability was measured by trypan blue exclusion and always exceeded 95\%.

Cytokine preincubation

IL- $1 \beta$, IL-6, and TNF- $\alpha$ were obtained from R\&D Systems (Uithoorn, The Netherlands). Preincubation of the mesothelial monolayer and tumor cells was performed using increasing concentrations of these mediators.

Anti-human IL- $1 \beta$ and anti-human TNF- $\alpha$ were obtained from $\mathrm{R} \& \mathrm{D}$ Systems. To inactivate IL- $\beta$, preincubation was performed with a hundredfold excess of anti-IL-1 $\beta$ for 1 hour at $37^{\circ} \mathrm{C}$ according to the instructions of the manufacturer. After this, the formed IL- $1 \beta /$ anti-IL- $1 \beta$ complex was added to the mesothelial monolayer for preincubation. Inactivation of TNF- $\alpha$ was performed in the same way as inactivation of IL- $1 \beta$.

\section{Calcein-AM solution and incubation}

The dye solution, calcein-AM, used to quantify tumor cell adhesion was prepared by dissolving $50 \mu \mathrm{g}$ calcein (Molecular Probes, Leiden, The Netherlands) in $5 \mu \mathrm{L}$ anhydrous dimethyl sulphoxide (Sigma-Aldrich, Zwijndrecht, The Netherlands) and adding this solution to $5 \mathrm{~mL}$ of RPMI 1640 medium supplemented with $0.5 \%$ bovine serum albumin (BSA; RPMI 1640/0.5\% BSA; Sigma-Aldrich). Trypsinized Caco 2 and HT29 cells $\left(1 \times 10^{6}\right.$ cells $\left./ \mathrm{mL}\right)$ were incubated in RPMI $1640 / 0.5 \%$ BSA at $37^{\circ} \mathrm{C}$ for 30 minutes with occasional mixing.

\section{Adhesion assay}

To quantify tumor cell adhesion to a monolayer mesothelium, a standardized cell adhesion assay was developed according to methods of Catterall et al [14]. Mesothelial monolayers were established in 96-well plates (Canberra Packerd, Groningen, The Netherlands), precoated with collagen type I $\left(15 \mu \mathrm{g} / \mathrm{cm}^{2}\right.$, coating according to instructions of the manufacturer). To do this, confluent cells were washed with phosphate-buffered saline (PBS) and harvested with trypsin, $(0.05 \%)$, EDTA $(0.02 \%)$, and $2.5 \times 10^{4} \mathrm{MC}$ were added to $200 \mu \mathrm{L}$ of medium to each well. The plates were incubated at $37^{\circ} \mathrm{C}$, in a humidified atmosphere of $5 \% \mathrm{CO}_{2}$ in air; the medium was replaced daily with fresh medium. Monolayers reached confluence in 5-7 days as determined by light microscopy. To determine the effect of the inflammatory cytokines on tumor cell adhesion, mesothelial monolayers were preincubated with increasing doses. Non-preincubated mesothelial monolayers served as controls.

Tumor cells were labeled with calcein as described. Before addition to the mesothelial monolayers, the labeled cells were washed twice with RPMI1640/0.5\% BSA to remove any free dye.

Medium from the experimental wells was removed and $200 \mu \mathrm{L}$ RPMI1640/0.5\% BSA containing 30,000 calceinlabeled tumor cells was added. Plates were centrifuged for 1 minute at $80 \mathrm{~g}$ on a Perkin Elmer centrifuge and incubated at $37^{\circ} \mathrm{C}$ for 60 minutes. After this, the medium of each well was removed and washed twice with $200 \mu \mathrm{L}$ RPMI1640/0.5\% BSA medium. The remaining fluorescence per well was measured on a Perkin Elmer plate reader using 485 excitation and 530 emission filters. On each plate, a standard was prepared by adding different numbers of labeled tumor cells to the wells. The number of tumor cells adhered was determined 
by calibrating the measured fluorescence of the experimental wells on the standard.

\section{DNA assay}

To investigate whether overnight incubation of the mesothelial monolayer with the different cytokines was influencing the cell growth, a DNA measurement was performed. In this assay, the DNA content of the MC was measured using the bisbenzimide fluorescent dye (Roche Diagnostics, Mannheim, Germany) as previously described by Hofland et al [15]. In short, at the end of the incubation period the plates were washed twice with saline and stored at $-20^{\circ} \mathrm{C}$ until further analysis. The cells were extracted with ammonia solution $(1 \mathrm{mmol} / \mathrm{L})$ Triton $\times 100(0.2 \% \mathrm{v} / \mathrm{v})$ by sonification for 5 seconds at amplitude 15 (Soniprep 150; MSE). Thereafter, assay buffer (100 mmol/L NaCl, $10 \mathrm{mmol} / \mathrm{L}$ EDTA, $10 \mathrm{mmol} / \mathrm{L}$ Tris; $\mathrm{pH}$ 7.0) was added. The remaining solution was centrifuged at $2000 \mathrm{~g}$ for 5 minutes and $100-\mu \mathrm{L}$ aliquots of the supernatant was mixed with $2 \mathrm{~mL}$ Hoechst dye H33258 (100 $\mu \mathrm{g} / \mathrm{L})$. Fluorescence was measured after 10 minutes with the excitation and emission wavelengths set at 350 and $455 \mathrm{~nm}$, respectively. The fluorescence of experimental samples were referenced to a standard curve of calf thymus DNA (type II; Sigma).
Growth curves

The effect of cytokines on tumor cell growth was investigated by incubating the tumor cell lines with $10 \mathrm{ng} / \mathrm{ml} \mathrm{IL-} \beta$, IL-6, or TNF- $\alpha$ overnight. Preincubation was initiated immediately after seeding of the tumor cells in 24-well plates. Growth response to IL- $1 \beta$, IL- 6 , and TNF- $\alpha$ (R\&D Systems) was studied at the indicated time points.

Expression of cytokine receptors and adhesion molecules

MC and the colon carcinoma cell lines were prepared for staining by cytospin preparation, fixed in acetone for 1 minute, and stored at $-20^{\circ} \mathrm{C}$ until use. The cytospins were preincubated for 15 minutes with $10 \%$ normal goat serum, diluted in PBS, and incubated overnight at $4^{\circ} \mathrm{C}$ with goat anti-human monoclonal antibodies to IL-1Ra, IL-6R, TNF-RI, TNF-RII, ICAM-1, VCAM-1, CD44, LFA-1, and VLA-4 (all obtained from R\&D Systems).

\section{Statistical analysis}

All data were analyzed using ANOVA to determine overall differences between group means. If the ANOVA was significant on a $5 \%$ level, the post hoc Newman-Keuls test was carried out to make a comparison between groups. $P \leq .05$
Fig. 1 Tumor cell adhesion of Caco2 (a) and HT29 (b) to a mesothelial monolayer after preincubation of the monolayer with $0.5,1,5,10,50$, or $100 \mathrm{ng} / \mathrm{mL}$ cytokine. Open bars represent IL- $1 \beta$ pretreated monolayers, closed bars the effect of IL-6 pretreated monolayers, and blocked bars the effect of TNF- $\alpha$. Values are the mean $(n=6)+$ SEM ${ }^{*} P<.01$
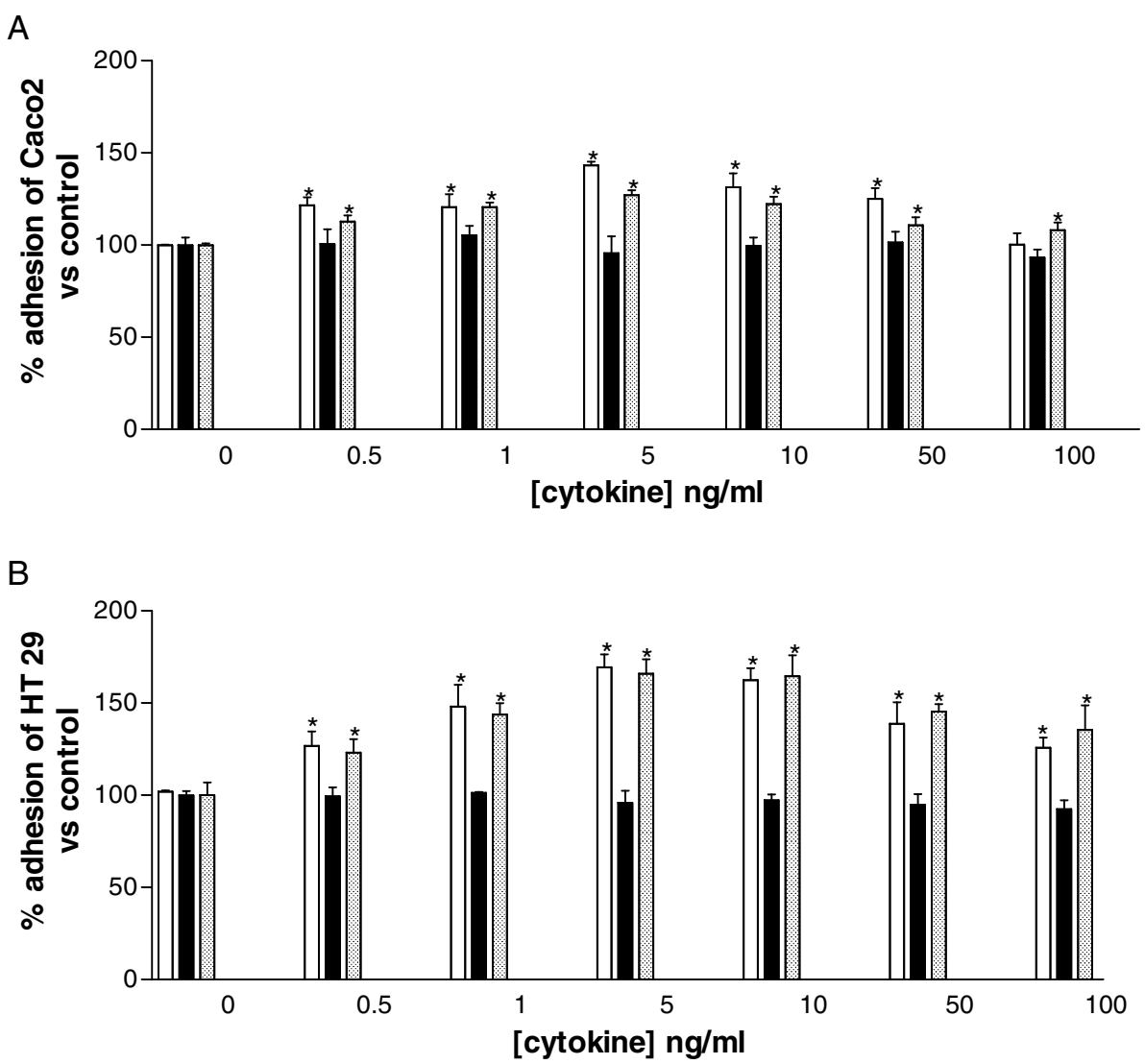
A

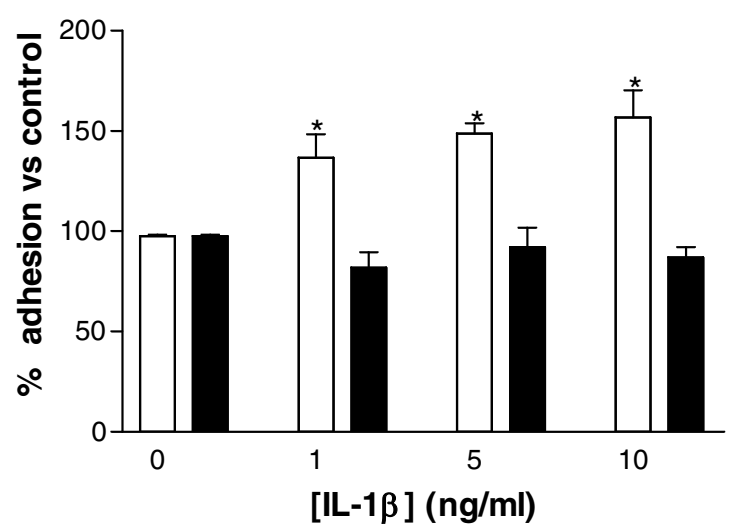

C

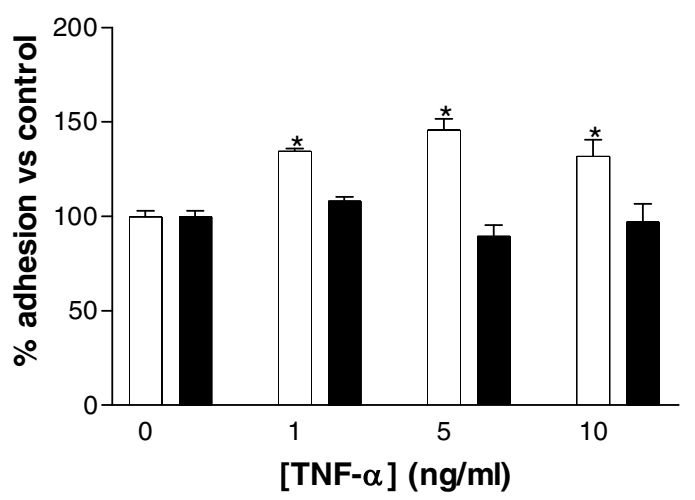

Fig. 2 Tumor cell adhesion of Caco2 (A/C) and HT29 (B/D) to a mesothelial monolayer after preincubation of the monolayer with 1,5 , or $10 \mathrm{ng} / \mathrm{mL} \mathrm{IL-1} \beta$ (open bars, (a) and (b)) or TNF- $\alpha$ (open bars, (c)

was considered statistically significant. Experiments were carried out at least twice with comparable results.

\section{Results}

Validation of assay

Loading of the tumor cells with calcein did not affect their viability ( $>95 \%$ using trypan blue). To determine the stability of calcein uptake, the release of fluorescence in the supernatant of labeled cells after an incubation time of up to 120 minutes was measured. The fluorescence of the washed cells stayed constant for at least 90 minutes, indicating retention of the dye in the cells (data not shown). A dilution series was made by using labeled Caco2 and HT29 cells on a mesothelial monolayer. There was a direct relationship between the cell number added and measured fluorescence, resulting in a linear correlation that was used as a standard to calibrate the measured fluorescence. In this way, the amount of adhered tumor cells in the experimental wells could be determined.
B

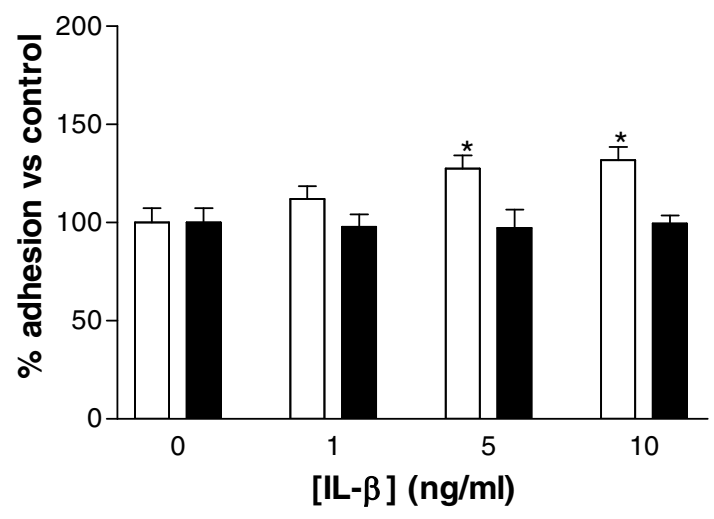

D

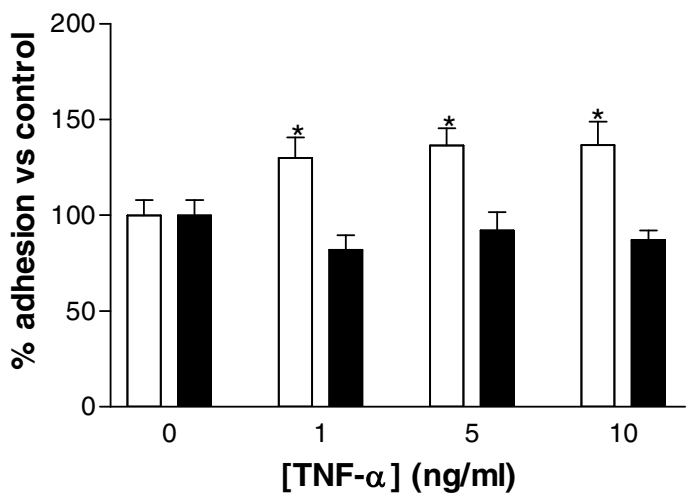

and (d). The closed bars represent the additional blocking with anti-IL$1 \beta(\mathrm{A} / \mathrm{B})$ or anti-TNF- $\alpha(\mathrm{C} / \mathrm{D})$. Values are the mean $(n=6)+\mathrm{SEM}$. ${ }^{*} P<.01$

Tumor cell adhesion to a mesothelial monolayer

Tumor cell adhesion to a non-preincubated mesothelial monolayer was relatively slow and temperature dependent. Maximum adhesion was seen after 60 minutes. At this time point, a steady state was achieved and cell adhesion did not increase thereafter. Tumor cells remained rounded up during these adhesion assays. After $>60$ minutes, the first signs of spreading out could be detected under the light microscope. Therefore, for all subsequent experiments, 60 minutes was taken as a cutoff point. Nonstimulated cell adhesion was always between $25 \%$ and $50 \%$ of the total amount of tumor cells added.

Table 1 Tumor cell adhesion to a mesothelial monolayer after preincubation of the tumor cells with cytokines $(5 \mathrm{ng} / \mathrm{mL})$

\begin{tabular}{lllll}
\hline & Control & IL-1 $\beta$ & TNF- $\alpha$ & IL-6 \\
\hline \% Adhesion Caco2 & $45 \pm 2$ & $47 \pm 3$ & $35 \pm 3$ & $41 \pm 4$ \\
\% Adhesion HT29 & $29 \pm 2$ & $31 \pm 3$ & $26 \pm 4$ & $33 \pm 2$ \\
\hline
\end{tabular}

Value are the mean of $n=6 \pm$ SD. 


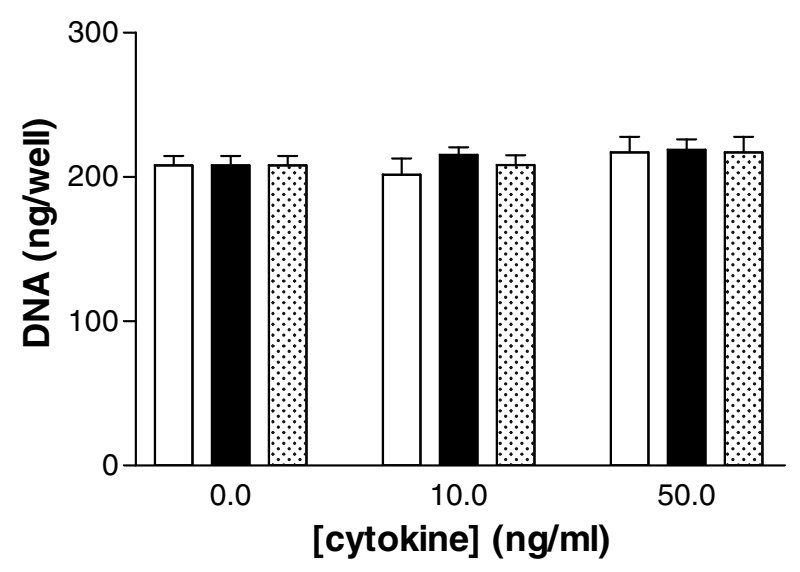

Fig. 3 The effect of IL-1 $\beta$ (open bars), IL-6 (closed bars), and TNF- $\alpha$ (blocked bars) on the proliferation of a mesothelial monolayer. Data are expressed as the mean $(n=6) \pm$ SEM. Preincubation did not significantly modify total DNA of the monolayer

Effect of cytokine preincubation

Preincubation of the mesothelial monolayer with IL- $1 \beta$ or TNF- $\alpha$ resulted in enhanced tumor cell adhesion of the Caco2 and HT29 cells. This effect was dose dependent. Maximum stimulation was achieved at $5 \mathrm{ng} / \mathrm{mL}(P<.01)$. The amount of stimulation for the Caco 2 cells was between $20 \%$ and $40 \%$ versus the control situation and for HT29 cells between $30 \%$ and $70 \%$. Contrary to IL- $1 \beta$ and TNF- $\alpha$, IL-6 (1-100 ng/mL) did not alter tumor cell adhesion to a mesothelial monolayer (Fig.1). After blocking with anti-IL$1 \beta$, stimulation with 1,5 , and $10 \mathrm{ng} / \mathrm{mL} \mathrm{IL-} \beta(0.1,0.5$, and $1.0 \mu \mathrm{g} / \mathrm{mL}$ anti-IL-1 $\beta$ ) was completely inhibited (Fig. 2).

Blocking with a hundredfold excess of anti-TNF- $\alpha$ inhibited the stimulatory effect of TNF- $\alpha$ as well (Fig. 2). Preincubation of the tumor cells with IL- $1 \beta$, TNF- $\alpha$, or IL-6 did not result in a significant increase of adhered tumor cells to the mesothelial monolayers (Table 1).

DNA assay

Overnight preincubation of a mesothelial monolayer with IL- $1 \beta$, IL-6, or TNF- $\alpha$ did not modify total DNA content of the mesothelial monolayer and therefore did not affect cell growth (Fig. 3). To investigate the influence of these cytokines on growing tumor cells, we measured the total DNA after 2 and 4 days of incubation of the tumor cells with IL- $1 \beta$, IL- 6 , or TNF- $\alpha(10 \mathrm{ng} / \mathrm{mL})$. The growth of Caco 2 and HT29 cells was inhibited after 4 days when the cells were grown in RPMI $164010 \%$ FCS enriched with TNF- $\alpha$ or IL-6 (10 ng/mL). IL- $1 \beta(10 \mathrm{ng} / \mathrm{mL})$ incubation of Caco 2 and HT29 cells resulted in a minor growth inhibition (Fig. 4). These results prove the functionality of the cytokine receptors on the tumor cells.
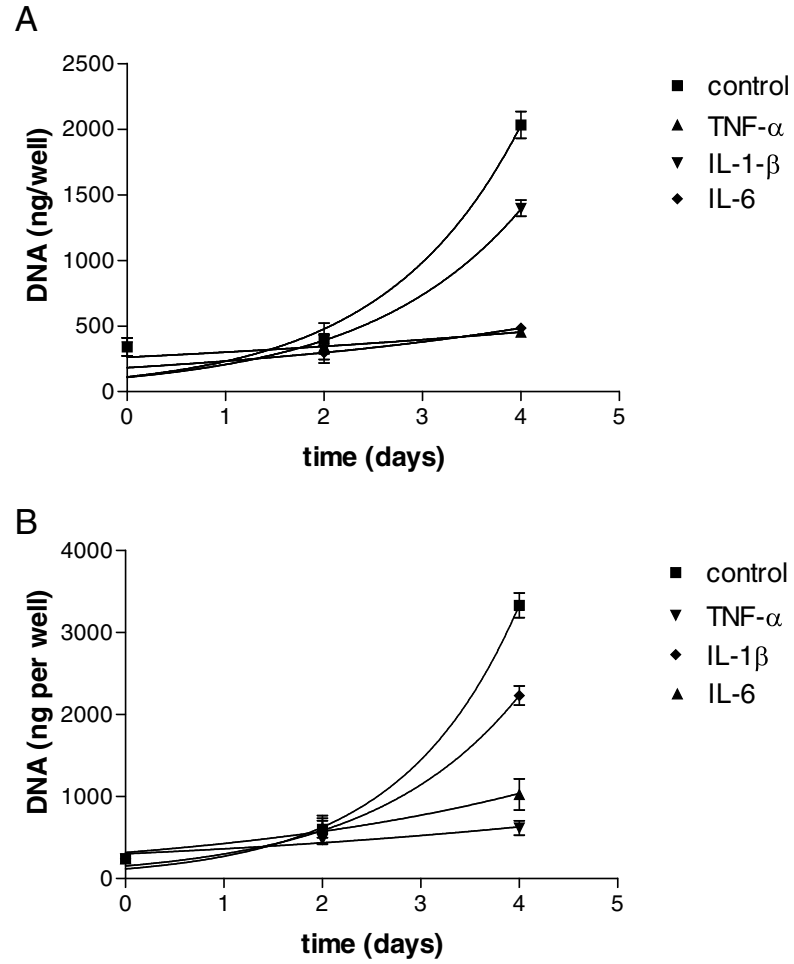

Fig. 4 Growth rate of 20,000 Caco2 (a) and HT29 (b) cells incubated with cytokines IL- $1 \beta$, IL- 6 , and TNF- $\alpha(10 \mathrm{ng} / \mathrm{mL})$ for 4 days

Expression of cytokine receptors and adhesion molecules

The results of the staining of MC are shown in Fig. 5 and clearly demonstrate that these cells express receptors for IL- $1 \beta$, IL- 6 , and TNF- $\alpha$. Table 2 shows the results of the immunohistochemical staining of the MC and colon carcinoma cancer cell lines with the adhesion molecules and counterparts. The MC stained positive for ICAM-1, VCAM1, and CD44. HT29 and Caco2 cell lines are both positive for ICAM-1, VCAM-1, CD44, LFA-1, and VLA-4. The negative controls, the positively stained $\mathrm{MC}$, and the counterparts on the colon carcinoma cell lines are shown in Fig. 6.

\section{Discussion}

Local recurrence of colorectal cancer is major clinical problem. Spilled tumor cells are preferentially distributed to the resection site, and combined recurrences to the resection site and peritoneal surfaces are common [3]. The mechanism behind this process has not been unraveled yet.

After abdominal surgery, there is a reactive inflammatory response, the acute phase response, during which cytokines and growth factors are produced [16]. These cytokines are known to be conducive to wound healing by initiating the cellular cascade in the course of which macrophages and leukocytes migrate to the injured site [17]. In addition to 


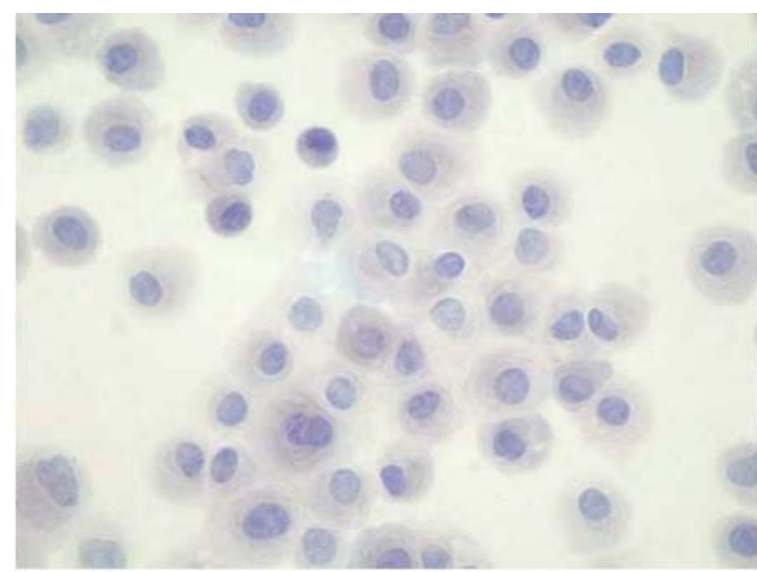

A

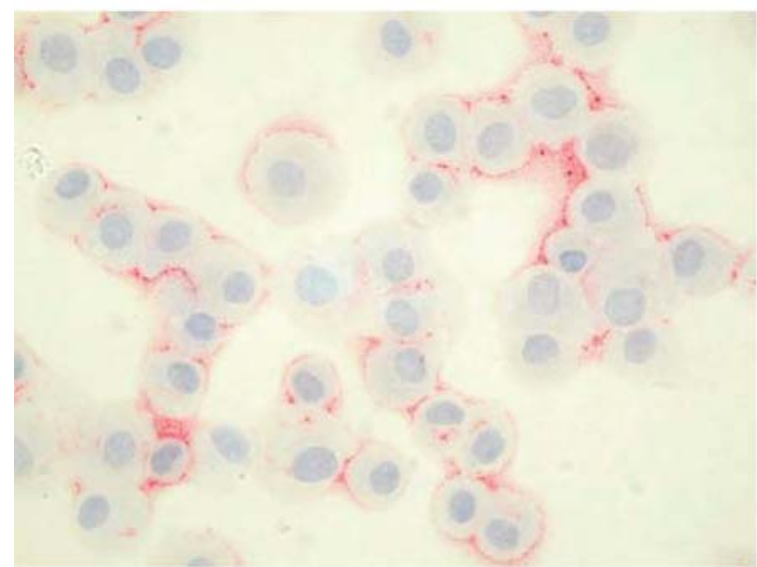

C

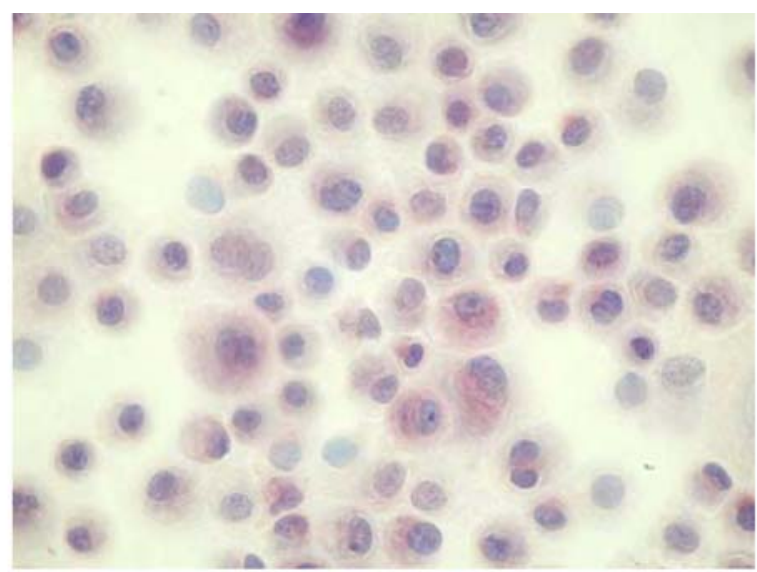

B

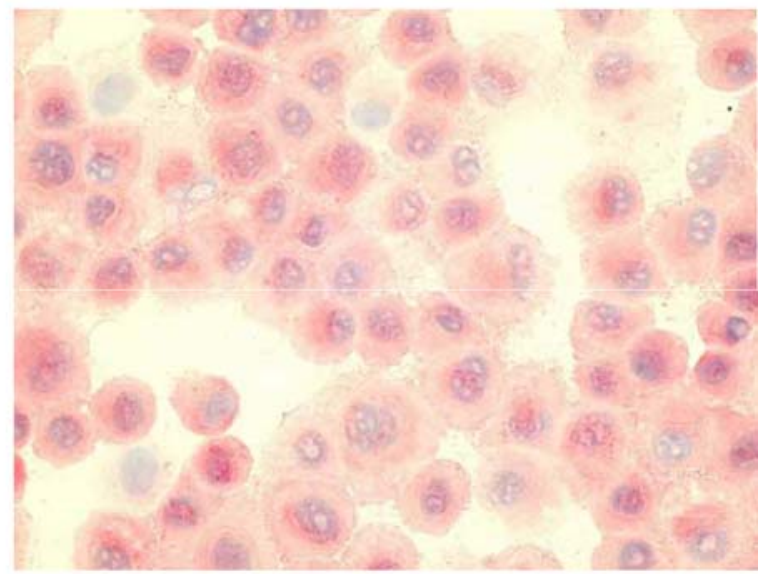

D

Fig. 5 Expression of cytokine receptors by MC. (a) Negative control. (b) IL-1 $\beta$ receptor. (c) IL-6 receptor. (d) TNF- $\alpha$ receptor

the production of cytokines by inflammatory cells, the MC can also produce several chemokines during peritoneal injury $[4,6]$. In our experiments, we evaluated the effects of the cytokines IL- $1 \beta$, Il- 6 , and TNF- $\alpha$ on the adhesion of colon carcinoma cells to mesothelial monolayers. IL- $1 \beta$ is one of the most investigated proinflammatory cytokine; its concentration in postoperative peritoneal fluid increases significantly. Therefore, it may be of great importance in the peritoneal cavity [18]. IL-6 is an early marker of tissue damage and the production of IL- 6 by MC is influenced by IL- 1 and TNF- $\alpha$ in a time- and dose-dependent manner [19-21]. TNF- $\alpha$ has a significant function in the abdominal cavity and might modulate the inflammatory response by inducing the production of ILs from MC [22, 23]. Postoperative concentrations of TNF- $\alpha$ in the peritoneal cavity are increased compared to IL-1 $\beta$ as well [18].

Our data advocate the enhancement of adhesion of Caco2 and HT29 cells to a mesothelial monolayer after incubation with IL- $1 \beta$ or TNF- $\alpha$ in a dose-dependent way. This effect was completely inhibited by blocking with anti-IL-1 $\beta$ and anti-TNF- $\alpha$, which underline the specificity of IL- $1 \beta$ and TNF- $\alpha$ stimulation and the involvement of a specific related pathway at which enhanced tumor cells adhesion to the mesothelial monolayer might be induced. Preincubation of the mesothelial monolayers with the different cytokines used in this study did not change the total DNA content and therefore demonstrate that the increased adhesion of colon carcinoma cells to the mesothelium is not caused by an enhanced number of MC. Other investigators demonstrate the same effect of cytokines on the enhancement of adhesion with

Table 2 Cell adhesion molecules and counterparts expressed by mesothelial, caco2, and HT29 cells according to immunohistochemical staining

\begin{tabular}{llllll}
\hline & ICAM-1 & VCAM-1 & CD 44 & LFA-1 & VLA-4 \\
\hline Mesothelial & + & + & + & - & - \\
Caco2 & + & + & + & + & + \\
HT29 & + & + & + & + & + \\
\hline
\end{tabular}




\section{Mesothelium}

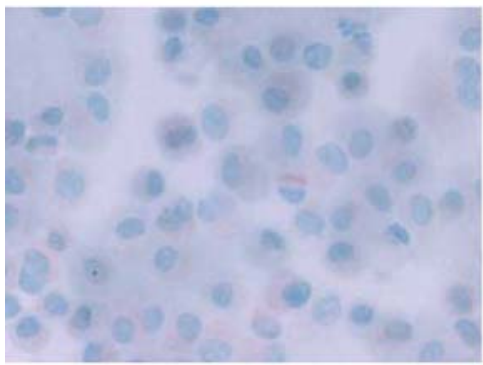

A

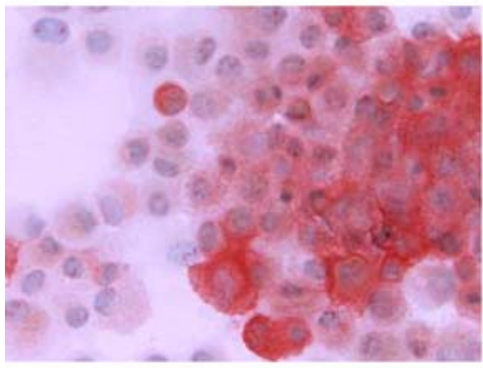

D

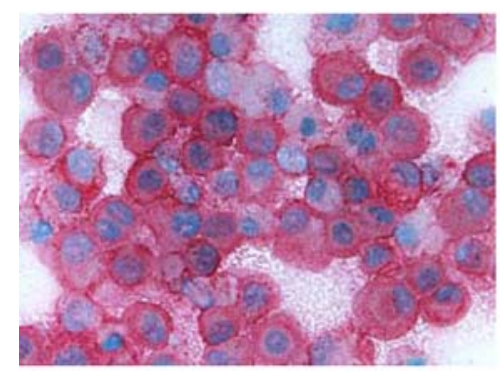

G

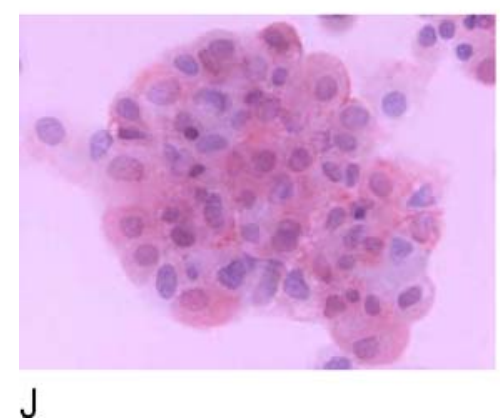

HT 29

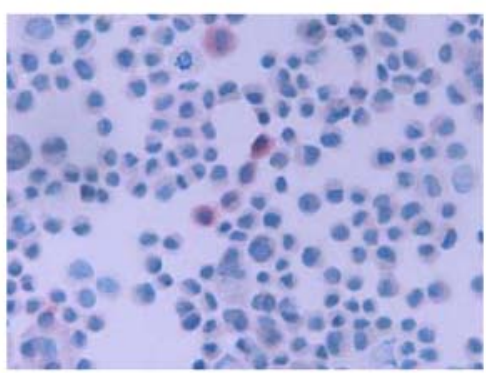

B

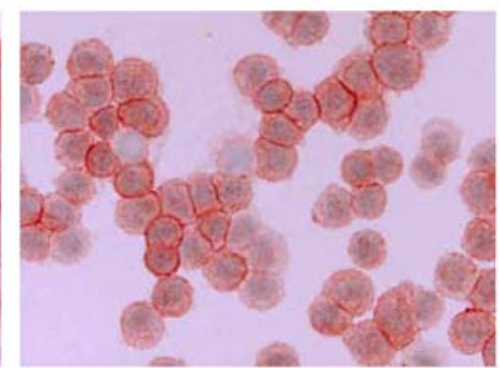

E

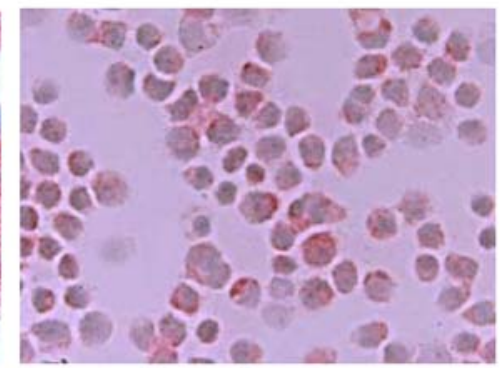

$\mathrm{H}$

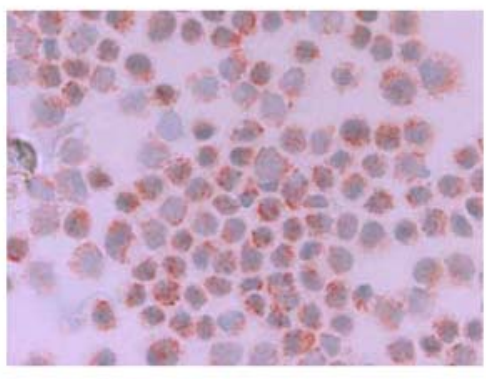

$\mathrm{K}$
Caco-2

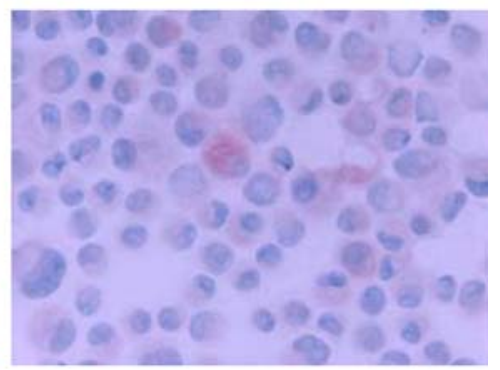

C

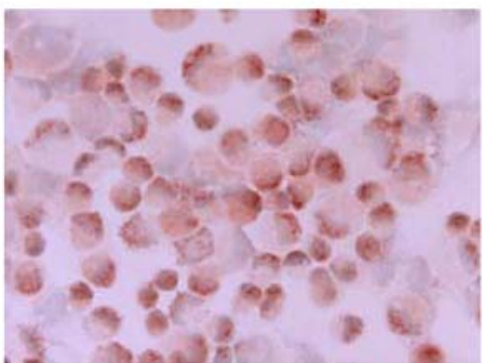

$\mathrm{F}$

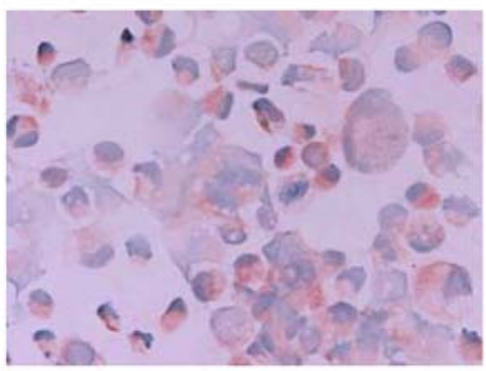

।

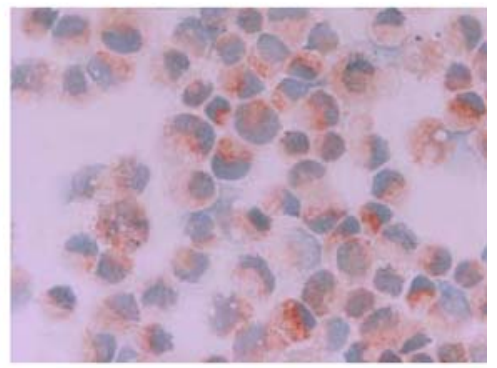

L

Fig. 6 Expression of cell adhesion molecules and counterparts after immunohistochemical staining of mesothelial, HT29, and Caco-2 cells. (a), (b), (c) negative control. (d), (e), (f) CD44. (g) ICAM-1. (h), (i) LFA-1. (j) VCAM-1. (k), (l) VLA-4

different tumor cell lines, like gastric tumor cells, melanoma cells, and ovarian tumor cells [24-27]. IL-1 $\beta$ and TNF- $\alpha$ are also potent stimulators of adhesion of colon carcinoma cells to endothelial cells [28].

The bell-shaped curves of cytokine-stimulated adhesion are most likely caused by the fact that a high concentration of cytokine may stimulate $\mathrm{MC}$ to produce mediators that can inhibit the stimulation of adhesion [29]. Another explanation might be the downregulation of cytokine receptors at high concentrations of the ligand.

Cytokines do not influence the growth of MC in contrast to their inhibitory effect on the growth of the colon carcinoma 
cell lines. This inhibitory effect demonstrates the functionality of the cytokine receptors on the colon carcinoma cell lines. Other studies have shown this suppressive effect of IL$1 \beta$ and TNF- $\alpha$ on proliferating colon carcinoma cell lines as well [30-32]. The inhibition of IL-6 on colon carcinoma cell growth has not been studied previously.

The enhancement of adhesion in this study is most likely originated by an upregulation of adhesion molecules. According to our immunohistochemical results, MC express ICAM-1, VCAM-1, and CD44. Caco2 and HT29 cells express, adjacent to the molecules expressed by the MC, the counterparts LFA-1 and VLA-4. These results suggest abundant possibilities for cell-cell and cell-matrix interactions under nonstimulated conditions. The expression patterns are similar to those observed in the literature. Several studies investigated the influence of TNF- $\alpha$ and IL- $1 \beta$ on the expression of adhesion molecules on MC. ICAM-1 and VCAM-1 expression is upregulated by these cytokines, which manifest the importance of these molecules in the interaction with colon carcinoma cells after stimulation of the mesothelium with IL- $1 \beta$ and TNF- $\alpha[7,8]$.

After stimulation of the colon carcinoma cell lines with the inflammatory cytokines, there was no remarkable enhancement of the adhesion to the mesothelial monolayer, suggesting that the mesothelial monolayer is the primary cell involved in increased adhesion induced by inflammatory cytokines. Expression of ICAM-1 on HT-29 and Caco2 cells is upregulated by TNF- $\alpha$ and IL- $\beta$; however, MC do not express their counterpart, LFA-1, which might be the explanation for the fact that there was not an enhancement of adhesion after stimulation of the colon carcinoma cell lines with the cytokines used in this study [33, 34].

In conclusion, inflammatory cytokines released following surgical wounding can cause an environment beneficial to tumor cell adhesion and possibly increases the metastatic potential of local tumor cells. This study demonstrates that the enhancement of colon carcinoma cells to a monolayer mesothelium is induced by IL- $\beta$ and TNF- $\alpha$. This enhancement might be derived from an upregulation of ICAM-1, VCAM-1, and CD44 on MC. Future experiments should determine which of the cell-cell and cell-matrix interactions are most important in tumor cell adhesion to develop sitespecific drug delivery systems and in that way block the tumor cells to adhere.

\section{References}

1. Guyot F, Faivre J, Manfredi S, Meny B, Bonithon-Kopp C, Bouvier AM (2005) Time trends in the treatment and survival of recurrence from colorectal cancer. Ann Oncol 16:756-761

2. Meyerhardt JA, Mayer RJ (2003) Follow-up strategies after curative resection of colorectal cancer. Semin Oncol 3:349360
3. Sugarbaker PH (1991) A perspective on clinical research strategies in carcinoma of the large bowel. World J Surg 15:609-616

4. Holmdahl L, Ivarsson ML (1999) The role of cytokines, coagulation, and fibrinolysis in peritoneal tissue repair. Eur J Surg 165:1012-1019

5. diZerega GS (1997) Biochemical events in peritoneal tissue repair. Eur J Surg Suppl (577);10-16

6. Nagy JA, Jackman R (1998) Response of the peritoneal membrane to injury. Semin Dialysis 11:242-248

7. Jonjic N, Peri G, Bernasconi S, Sciacca FL, Colotta F, Pelicci P, Lanfrancone L, Mantovani A (1992) Expression of adhesion molecules and chemotactic cytokines in cultured human mesothelial cells. J Exp Med 176:1165-1174

8. Klein CL, Bittinger F, Skarke CC, Wagner M, Kohler H, Walgenbach S, Kirkpatrick CJ (1995) Effects of cytokines on the expression of cell adhesion molecules by cultured human omental mesothelial cells. Pathobiology 63:204-212

9. Meager A (1999) Cytokine regulation of cellular adhesion molecule expression in inflammation. Cytokine Growth Factor Rev 10:27-39

10. Nicholson LJ, Clarke JMF, Pittilo RM, Machin SJ, Woolf N (1984) The mesothelial cell as a non-thrombogenic surface. Thromb Haemostas 52:102-104

11. Wu YJ, Parker LM, Binder NE, Beckett MA, Sinard JH, Griffiths T, Rheinwald JG (1982) The mesothelial keratins: an new family of cytoskeletal proteins identified in cultured mesothelial cells and nonkeratinizing epithelia. Cell 31:693-703

12. Pronk A, Leguit P, Hoynck van Papendrecht AAGM, Hagelen E, van Vroonhoven TJMV, Verbrugh HA (1993) A cobblestone cell isolated from the human omentum: the mesothelial cell; isolation, and growth characteristics. In Vitro Cell. Dev. Biol. 29A:127-134

13. Connell ND, Rheinwald JG (1983) Regulation of the cytoskeleton in mesothelial cells: reversible loss of keratin and increase in vimentin during rapid growth in culture. Cell 34:245-253

14. Catterall JB, Gardner MJ, Jones LMH, Thompson GA, Turner GA (1994) A precise, rapid and sensitive in vitro assay to measure the adhesion of ovarian cells to peritoneal mesothelial cells. Cancer Lett 87:199-203

15. Hofland LJ, Koetsveld PM, Lamberts SW (1990) Percoll density gradient centrifugation of rat pituitary tumor cells: a study of functional heterogeneity within and between tumors with respect to growth rates, prolactin production and responsiveness tot the somatostatin analog SMS 201-995. Eur J Cancer 26:37-44

16. Brulez HFH, Verbrugh HA (1995) First-line defense mechanisms in the peritoneal cavity during peritoneal dialysis. Perit Dial Int 15(7 Suppl):24-34

17. Slavin J (1996) The role of cytokines in wound healing. J Pathol 178:5-10

18. Tsukada K, Katoh H, Shiojima M, Suzuki T, Takanoshita S, Hagamachi Y (1993) Concentrations of cytokines in peritoneal fluid after surgery. Eur J Surg 159:475-479

19. Shenkin A, Fraser WD, Series J, Winstanley FP, McCartney AC, Burns HJ, Van Damme J (1989) The serum interleukin 6 response to elective surgery. Lymphokine Res 8:123-127

20. Lanfrancone L, Boraschi D, Ghiara P, Falini B, Grignani F, Peri G, Mantovani A, Pelicci PG (1992) Human peritoneal mesothelial cells produce many cytokines (granulocyte colony-stimulating factor [CSF], granulocyte-monocyte-CSF, macrophage-CSF, interleukin-1 [IL-1], and IL-6) and are activated and stimulated to grow by IL-1. Blood 80:2835-2842

21. Topley N, Jorres A, Luttmann W, Petersen MM, Lang MJ, Thierauch KH, Muller C, Coles GA, Davies M, Williams JD (1993) Human peritoneal mesothelial cells synthesize interleukin-6: induction by IL- $1 \beta$ and TNF $\alpha$. Kidney Int 43:226-233

22. Betjes MG, Tuk CW, Struijk DG, Krediet RT, Arisz L, Hart M, Beelen RH (1993) Interleukin-8 production by human 
peritoneal mesothelial cells in response to tumor necrosis factor-a, interleukin-1, and medium conditioned by macrophages cocultured with staphylococcus epidermidis. J Infect Dis 168:1202-1210

23. Douvdevani A, Rapoport J, Konforty A, Argrov S, Ovnat A, Chaimovitz C (1994) Human peritoneal mesothelial cells synthesize IL-1 alpha and beta. Kidney Int 46:993-1001

24. Hofer SOP, Shrayer D, Reichner JS, Hoekstra HJ, Wanebo HJ (1998) Wound-induced tumor progression. A probable role in recurrence after tumor resection. Arch Surg. 133:383-389

25. Nakashio T, Narita T, Akiyama S, Kasai Y, Kondo K, Ito K, Takagi H, Kannagi R (1997) Adhesion molecules and TGF- $\beta 1$ are involved in the peritoneal dissemination of NUGC-4 human gastric cancer cells. Int J Cancer 70:612-618

26. Niedbala MJ, Crickard K, Bernacki RJ (1985) Interactions of human ovarian tumor cells with human mesothelial cells grown on extracellular matrix. Exp Cell Res 160:499-513

27. Lessan K, Aguiar DJ, Oegema T, Siebenson L, Skubitz AP. CD44 en beta1 integrin mediate ovarian carcinoma cell adhesion to peritoneal mesothelial cells (1999) Am J Pathol 154:1525-1537

28. Dejana E, Bertocchi F, Bortolami MC, Regonesi A, Tonta A, Breviario F, Giavazzi R (1988) Interleukin 1 promotes tumor cell adhesion to cultured human endothelial cells. J Clin Invest 82:14661470
29. Mutsaers SE, McAnulty RJ, Laurent GJ, Versnel MA, Whitaker D, Papadimitriou JM (1997) Cytokine regulation of mesothelial cell proliferation in vitro and in vivo. Eur $\mathrm{J}$ Cell Biol 72:24-29

30. Schiller JH, Bittner G (1990) Anti-proliferative effects of tumor necrosis factor, gamma interferon and 5-fluorouracil on human colorectal carcinoma cell lines. Int J Cancer 46:61-66

31. Dohlsten M, Sundstedt A, Bjorklund M, Hedlund G, Kalland T (1993) Superantigen induced cytokines suppress growth of human colon-carcinoma cells. Int J Cancer 54:482-488

32. Raitano AB, Korc M (1993) Growth inhibition of a human colorectal carcinoma cell line by interleukin 1 is associated with enhanced expression of gamma-interferon receptors. Cancer Res 53:636640

33. Dippold W, Wittig B, Schwaeble W, Mayet W, Meyer zum Buschenfelde KH (1993) Expression of intercellular adhesion molecule 1 (ICAM-1, CD54) in colonic epithelial cells. Gut 34:1593-1597

34. Kaiserlian D, Rigal D, Abello J, Revillard JP (1991) Expression, function and regulation of the intercellular adhesion molecule-1 (ICAM-1) on human intestinal epithelial cell lines. Eur J Immunol 21:1415-2421 